\title{
EFFECTS OF ANCHORING GROUPS ON ORGANIC SENSITIZERS FOR DYE-SENSITIZED SOLAR CELLS: A FIRST PRINCIPLE STUDY
}

\author{
Madhu Prakasam ${ }^{1}$ and S Tamilarasu ${ }^{2}$ \\ ${ }^{1}$ Thiruvalluvar University College of Arts and Science, Thiruppatur, Tamil Nadu, India \\ ${ }^{2}$ Jayam Arts and Science College
}

July 13, 2020

\begin{abstract}
A series of rigid triphenylamine (TPA) dyes have been designed with the donor (D)- $\pi$-acceptor (A) architecture. To screen the acceptor moities, we have design that's A1 and A2. The design sensitizer to evaluate the parameters such as geometries, electronic structures, and optical properties, along with dipole moment, polarizability and first-order hyperpolarizability were calculated using density functional theory (DFT) and time-dependent DFT (TD-DFT). Photo physical properties like wavelength of maximum absorption ( $\lambda \max$ ), oscillator strength (f), light harvesting efficiency (LHE) and dipole moment ( ) have been analyzed. Based on the results A2 acceptor moities having good photo physical properties, so this A2 based dyes having good sensitizer for dye sensitized solar cells application.
\end{abstract}

\section{Hosted file}

Manuscript.doc available at https://authorea.com/users/342335/articles/469131-effectsof-anchoring-groups-on-organic-sensitizers-for-dye-sensitized-solar-cells-a-firstprinciple-study

\section{Hosted file}

Figure.doc available at https://authorea.com/users/342335/articles/469131-effectsof-anchoring-groups-on-organic-sensitizers-for-dye-sensitized-solar-cells-a-firstprinciple-study

\section{Hosted file}

Table.doc available at https://authorea.com/users/342335/articles/469131-effects-ofanchoring-groups-on-organic-sensitizers-for-dye-sensitized-solar-cells-a-firstprinciple-study 